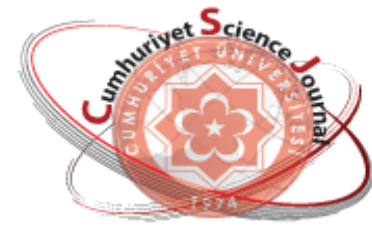

e-ISSN: $2587-246 X$

ISSN: $2587-2680$

\section{Cumburisy ot Seience Journal esJ}

Cumhuriyet Sci. J., Vol.39-2(2018) 524-530

\title{
Source Rock Characterictic of The Kızldere Clays (ARSUZ-HATAY)
}

\author{
Esef KILINÇ ${ }^{1}$, Meryem YEŞILOT KAPLAN ${ }^{2}$ \\ ${ }^{1}$ Adiyaman University, Technology Transfer Office, Engineering Faculty, Adiyaman, TURKEY \\ ${ }^{2}$ İskenderun Technical University, Department of Oil and Natural Gas Engineering, İskenderun, Hatay TURKEY \\ Received: 01.06.2018; Accepted: 07.06.2018 \\ http://dx.doi.org/10.17776/csj.429709
}

\begin{abstract}
Iskenderun Bay is the extension of the Adana Basin and is a convenient place for hydrocarbon exploration in terms of its formation mechanism. It is necessary to find rocks that can display lithological properties of source, reservoir and cover rocks in the mechanism of oil formation. There are formations in reservoir and cover rock lithology in İskenderun basin.
\end{abstract}

Kizıldere formation, which is the main rock, has gray-colored sandstone claystone sequences. Sandstones are $10-50 \mathrm{~cm}$ thick and claystones $2-30 \mathrm{~cm}$ thick. Stratified gypsium levels are observed at the top of the succession of sandstone and claystone and the thickness of the layers is between 5 and $15 \mathrm{~cm}$. The hydrocarbon production of Kizıldere Formation clay was found by calculating the amount of TOC (Total Organic Carbon) and the average value was $0.56 \%$. In addition, TOC values in the region are higher in the north and north east of the region and decrease in the south.

The sandstones in the region where the tectonic fractures are abundant due to MisisAndirın systems are reservoir rocks, and the evaporitic units known as Haymaseki formation are cover rocks.

Keywords: Total Organic Carbon, TOC, Kızıldere Formation.

\section{Kızıldere Killerinin (ARSUZ-HATAY) Ana Kaya Karakteristikleri}

Özet: İskenderun körfezi, Adana Havzasının devamı niteliğindedir ve oluşum mekanizması bakımından hidrokarbon aramaları için uygun yerdir. Petrol oluşum mekanizmasında ana kaya, rezervuar ve örtü kaya litolojik özelliklerini gösterebilecek kayaların bulunması gerekmektedir. İskenderun havzasında rezervuar ve örtü kaya litolojisinde formasyonlar mevcuttur.

Ana kaya olan Kızıldere formasyonu gri renkli kumtaşı kiltaşı ardışımlarından meydana gelmektedir. Kumtaşları katmanları 10-50 cm kalınlığındadır ve kiltaşı katmanlarının kalınlıkları ise 2-30 cm arasında değişmektedir. Kumtaşı ve kiltaşı ardışımının üstünde yer yer tabakalı jibs seviyeleri gözlemlenmektedir ve katman kalınlıkları 5-15 cm arasındadır.

Kızıldere Formasyonu killerinin hidrokarbon üretimi TOK(Toplam Organik Karbon) miktarının hesaplanmasıyla bulunmuştur ve bu değer ortalama \%0.56 olarak belirlenmiştir. Ayrıca bölgede TOC değerlerinin bölgenin Kuzey ve Kuzey doğusunda yüksektir ve güneye gidildikçe azalma görülmüştür.

Misis yükselimine bağlı olarak tektonik çatlakların bol görüldüğü bölgece kiltaşı kumtaşı ardışımlı formasyonda kumtaşlarının rezervuar kaya, üzerine gelen Haymaseki formasyonu olarak bilinen evaporitik birimler ise örtü kaya niteliğindedir.

Anahtar Kelimeler: Toplam Organik Karbon, TOK, Kızıldere Formasyonu

\footnotetext{
* Corresponding author. Email address: esefkilinc@adiyaman.edu.tr

http://dergipark.gov.tr/csj $\quad$ C2016 Faculty of Science, Cumhuriyet University
} 


\section{INTRODUCTION}

The potential for hydrocarbons formation of a sedimentary basin can be approximately determined using organic geochemical data. Hydrocarbon production occurs in the source rocks, accumulation in the reservoir rocks. The rocks, called the source rocks, are a general name given to rocks producing oil and / or natural gas. The thermal age and the amount of organic matters $(\mathrm{OM})$ of source rock are higher than other rocks. The most common analyzes made at source rocks are total organic material (TOC) and total organic material (TOM).

TOC (\%) analysis is an analytical technique that measures the total amount of organic carbon in the rocks. Total organic carbon, the result of the sum of the amounts of carbon derived of kerogen and hydrocarbons derived from kerogen in the rock [1].

TOC analyzes are usually made by pyrolytic methods, but organic materials can also be measured by laser based spectrometric methods recently [2,3]. TOC can be measured directly and quickly during logging when the well is opened [4].

TOC ratio in the source rock can be correlated with the sedimentation environment. This type of issue was studied by Baumgardner and Hamlin [5] in Texas mudstones with high organic matter concentration and revealed facies-TOC relationship.

Analyzes of organic matter-rich claystones are made in the source rock exploration. However, a rock rich in organic carbon may not be enough to become the source rock. Maturity of organic matter has an important role in hydrocarbon production. The source rocks are darker in color due to the oxidation of the organic material that they contain. Depending on the increase in the total amount of organic carbon in the shales, the color of the rock is changed from red to green, green and gray [6]. Black shales, clayey limestones and marls have the potential to be the source rock [7]. The source rocks of the shales contain at least $1 \%$ organic matter and $0.50 \%$ total organic carbon [8].

The study area consists of Konacik, Tülek, Işıklı in Arsuz-HATAY (Figure 1), which have been deposited in the Neogene period and known as the Iskenderun basin. The Iskenderun basin was first named by the Aksu and Demirkol [9] as the "Iskenderun Neogene As Basin".

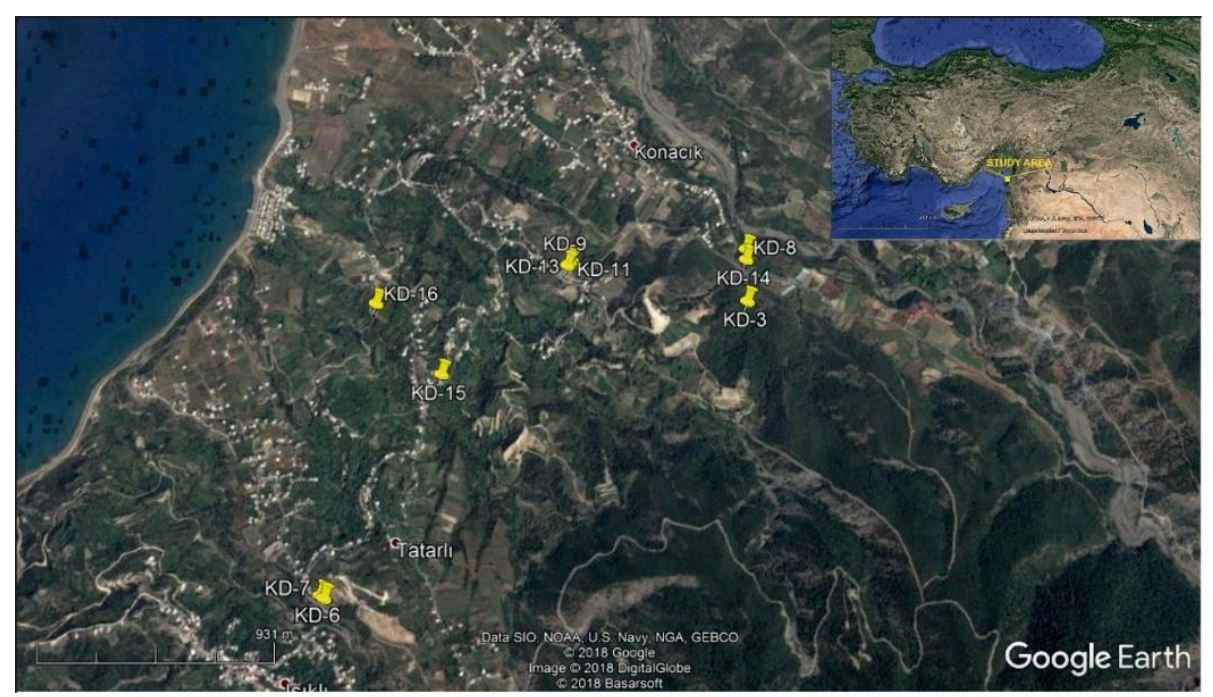

Figure 1. Study area and sample locations. 


\section{MATERIAL METHOD}

TOC analysis basically relies on the principle of determining the percentage of total carbon (TC) and inorganic carbon (IC) in the sample and subtracting the percentage of inorganic carbon from the total carbon percentage to find the total organic carbon (TOC) percentage.

$\mathrm{TC}-\mathrm{IC}=\mathrm{TOC}(\%)$

TC percentage is first determined in the TOC device. This process determines the percentage of the total carbon content by using dry air as a carrier gas at $200^{\circ} \mathrm{C}$ on the TC arm of the sample in the high temperature porcelain boots. Then, the samples are taken from the same specimen and the amount of inorganic carbon is determined in percentage by using $5 \%$ to $1 \%$ phosphoric acid $\left(\mathrm{H}_{3} \mathrm{PO}_{4}\right)$ in the porcelain container at $200^{\circ} \mathrm{C}$ on the IC line of the device.Geology of the Region

The Iskenderun basin is surrounded by the Taurus Mountains in the north, the Yumurtalık fault associated with Misis-Andırın systems in the west and the Amanos Mountains in the east. Kizıldağ ophiolite is formed in Paleozoic and Mesozoic era, and this unit is overlain by Neogene, which is composed of Kalecik formation, Horu formation, Kizıldere formation, Menzelet formation, Haymaseki formation and Aktepe formation. Neogene sedimentation begins with the Middle Miocene transgression $[10,11]$.

The Miocene deposits, unconformably located on the ophiolites started with coarse clastics (Kalecik formation). The reefal limestones (Horu formation) are located on the lacustrine formation of Kalecik and Kizildere formation where sandstone-shale succession is observed [11, 12, 13]. Evaporitic units (Haymaseki formation) deposited on the Kizıldere formation due to sea regression during the Messianic period after the marine units (Aktepe formation) began to deposit into the sea by transgression. Transgression continued in the Lower Pliocene, and the basin was closed with sediments where the river facies dominated the Upper PlioceneQuaternary.

The source rock Kizıldere formation was first named by [12]. The measured thickness of the formation consisting of gray colored thickmedium sandstone-claystone sequences is 800 $2500 \mathrm{~m}$. The Menzelet formation consisting of light gray sandy marls with transition lithology between Kizıldere formation and Haymaseki formation is in conformity with Kizıldere formation. Aktepe formation is unconformity unit top the Kizildere formation. The presence of planktonic foraminifera such as Globigerinoides bulloideus, G.bolli, G.trilobus, G.quadrilobatus, G. ruber,G. sacculifer, $G$. subquadratus, Orbulina universa, O. suturalis, O. bilobata, Praeorbulina glomerosa glomerosa, P. glomerosa curva, Globoquadrina venezuelana, Globigerinella obesa, Paragloborotalia mayeri indicates the MiddleLate Miocene age [14].

The Haymaseki formation, which consists of laminated sandy shales and contains different sizes of evaporitic units, was included in the Kizildere formation by some researchers $[14,15]$. The unit is composed of succession claystone and sandstone in very thin bands at intermediate levels with limestone and gypsum stratification.

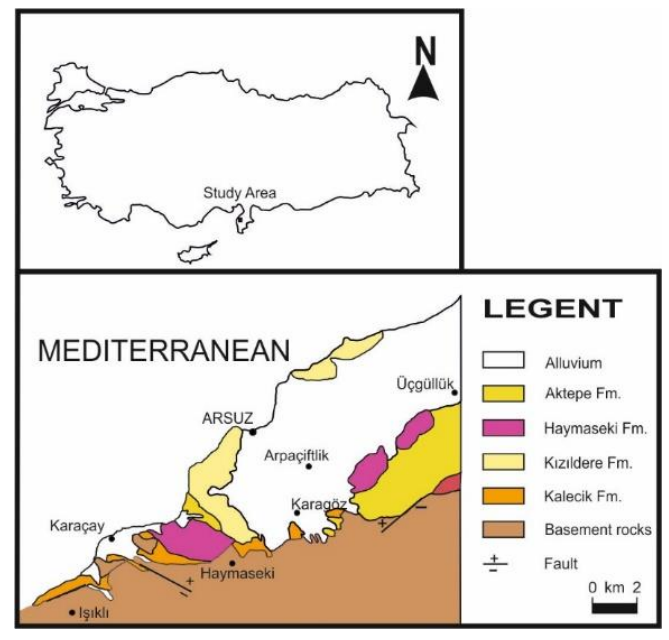

Figure 2. Geological map of the study area [16.] 


\section{FIELD OBSERVATIONS}

The petroleum-bearing regions formed during the Miocene period and formations; Kalecik Formation (Middle Miocene) composed of conglomerates, Horu Formation (Middle Miocene) composed of reefal limestones and Kizıldere Formation. Among these units, Kizıldere formation, which provides the characteristics of reservoir rock with Horu formation and oil reservoir rock source rock and cover rock, is important. The Middle-Late Miocene aged formation is typically observed in the Konacik (Arsuz) region. Sand and clay
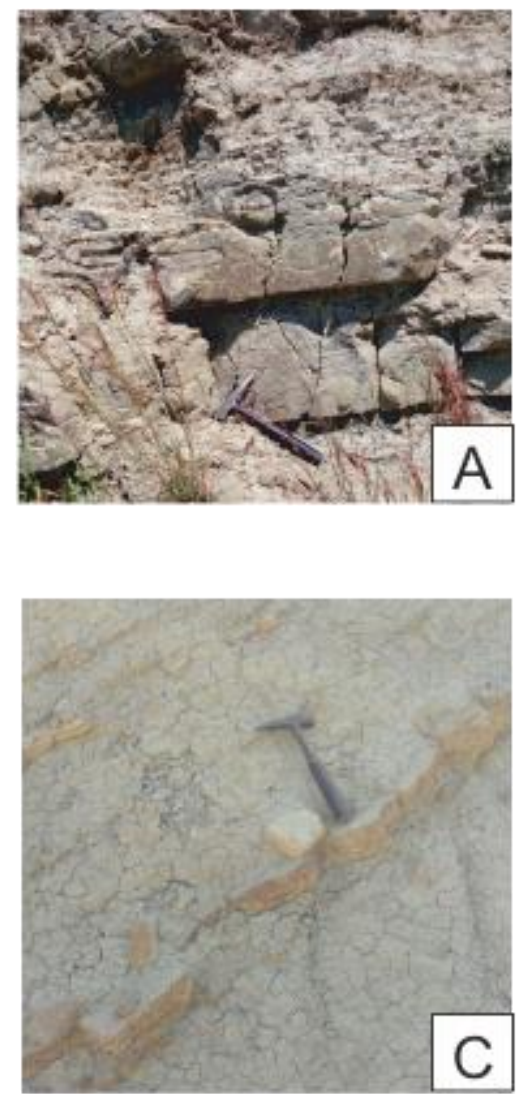

thickness of the formation is common of successive gray-yellow sandstones mediumthick layer between 10 to $50 \mathrm{~cm}$ (Fig 3A-B), the gray claystone between $2-30 \mathrm{~cm}$ are fine to medium layer (Figure 3-C). Stratified gypsium levels are observed at the top of the succession of sandstone and claystone and the thickness of the layers is between 5 and $15 \mathrm{~cm}$. Tectonic fractures are widely found in the formation due to the effect of tectonism after the Middle Miocene (Figure 3-D). Plant residues can be seen in the sequenced marls with gypsum.
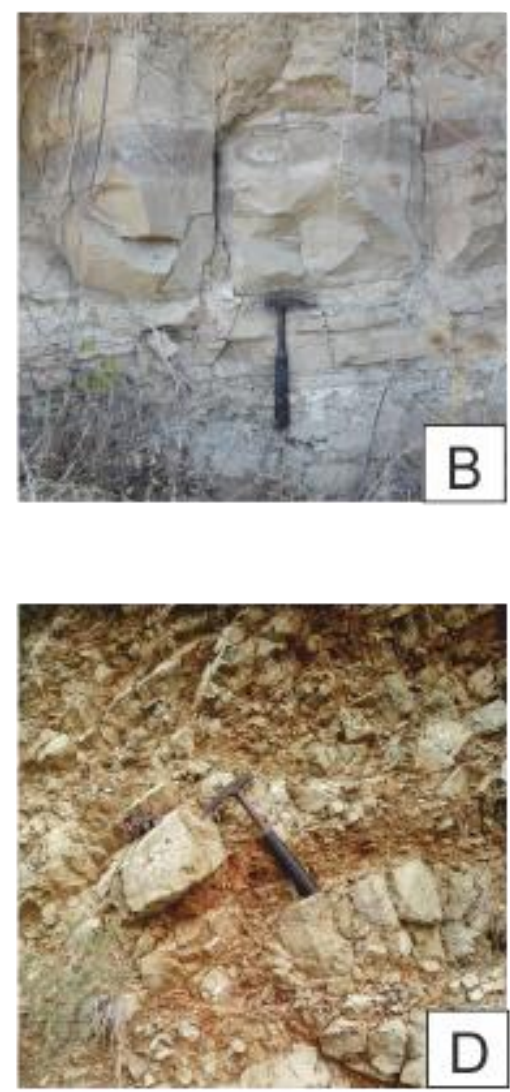

Figure 3. Field observations of Kizıldere formation, (A) Cracked sandstone strata, (B) Gray-colored claystone-sandstone succession, (C) claystone with fine sandstone layers, (D) claystone-sandstone layers formed by the effect of tectonics.

\section{AMOUNT of TOTAL ORGANIC CARBON}

The total Organic Carbon averages of the claystones, which are found in succession with the sandstones and marls taken from the region, are $0.56 \%$ (Table 2). This value is determined by Ruble et al. [17] indicate that claystones can product oil and natural gas (Table 3). Total organic carbon values are 6-23\% (mean 13\%) of the total carbon content in claystones, and the inorganic carbon content is high in the rocks, which generally have a high total organic carbon content. Figure 4 shows contour and 3D diagram maps plotted according to TOC values. 
Table 2. Sample location and total, inorganic, organic carbon ratio of Kizıldere claystones.

\begin{tabular}{lccccc}
\hline \multirow{2}{*}{ Sample } & \multicolumn{2}{c}{ GPS Coordinates } & \multirow{2}{*}{ Total Carbon $(\%)$} & IR Carbon $(\%)$ & \multirow{2}{*}{ TOC (\%) } \\
\cline { 2 - 4 } & Latitude & Longitude & & 0,01303 & 0,1054 \\
KD-1 & 754711.40 & 4025913.47 & 0.1184 & 2,7615 & 0,5110 \\
KD-6 & 753015.84 & 4024689.96 & 3,2725 & 3,681 & 0,8345 \\
KD-7 & 753030.08 & 4024679.75 & 4,5155 & 3,514 & 0,2385 \\
KD-8 & 754704.88 & 4026135.61 & 3,7525 & 4,7165 & 0,5260 \\
KD-9 & 753958.00 & 4026051.00 & 5,2425 & 4,4885 & 0,7615 \\
KD-11 & 753967.00 & 4026062.00 & 5,250 & 4,8385 & 0,5415 \\
KD-13 & 753976.00 & 4026075.00 & 5,380 & 2,6345 & 0,4105 \\
KD-14 & 754706.19 & 4026091.01 & 3,045 & 2,620 & 0,7845 \\
KD-15 & 753451.88 & 4025581.70 & 3,4045 & 3,0565 & 0,4335 \\
KD-16 & 753166.41 & 4025871.88 & 3,490 & & \\
\hline
\end{tabular}

Table 3. Rock classification by total organic carbon ratio [17].

\begin{tabular}{ll}
\hline Quality & TOC $(\mathrm{wt} \%)$ \\
\hline Poor & $<0.5$ \\
Fair & $0.5-1$ \\
Good & $1-2$ \\
Very Good & $2-4$ \\
Excellent & $>4$ \\
\hline
\end{tabular}

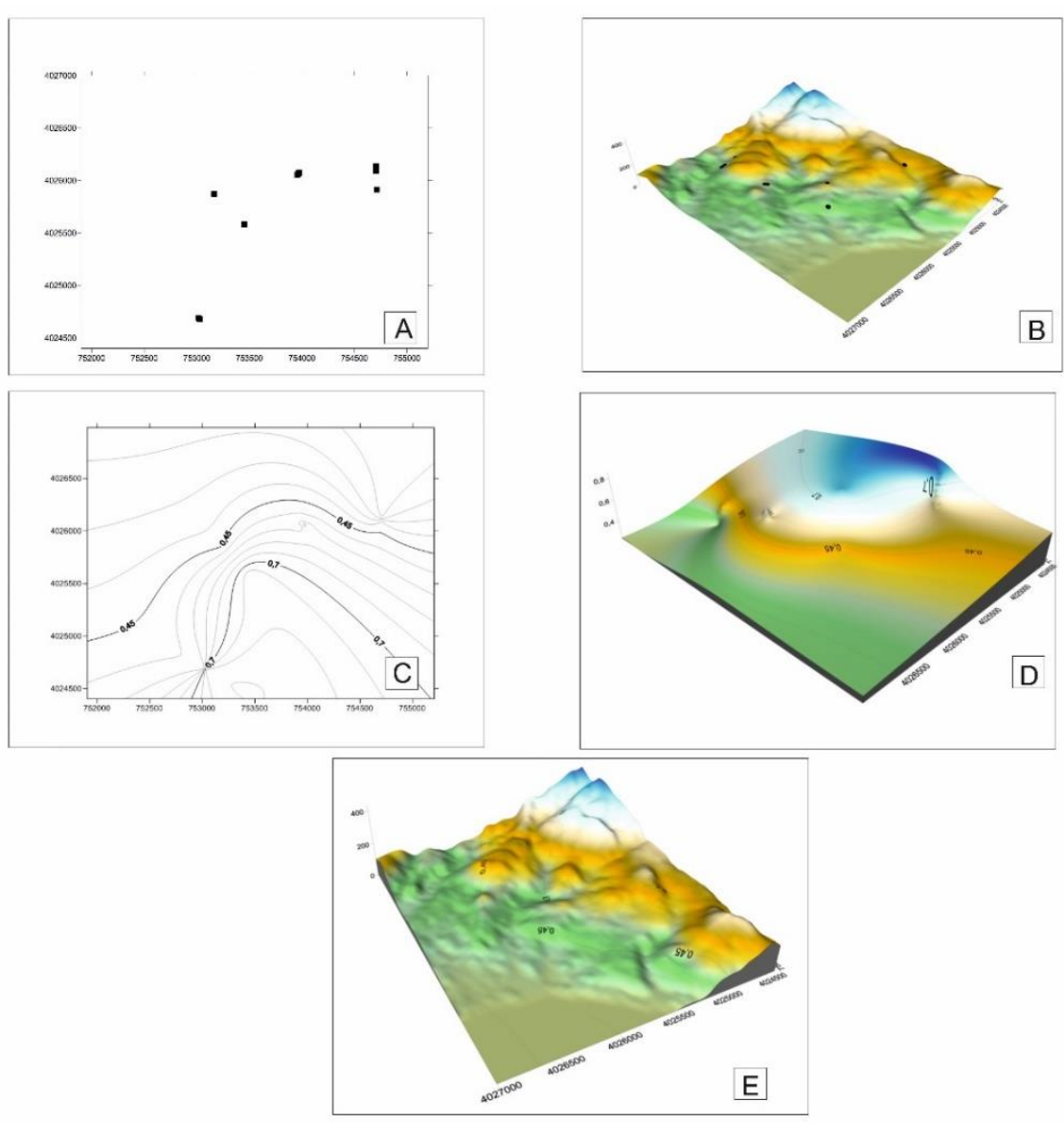

Figure 4. (A) Map showing sample locations, (B) Representation of sample locations in 3D block diagram, (C) Local contour map of TOC values in claystones, (D) 3D block diagram with TOC values in claystones, (E) Topographic distribution of TOC values. 


\section{RESULTS}

Field observations of Kizıldere sandstones and claystones that form in the lagoonal environment and layer evaporitic units, total organic carbon (TOC) contents and determination of plant residues are important in determining the oil potential. TOC values of claystones indicate that they can produce hydrocarbons.

Total Organic Carbon averages are 0.56 in the claystone samples. This value is determined by [17] shows that claystones can produce oil. The TOC values in the region are decreasing from north to southwest. This change suggests that claystones in the north east of the region are more likely to produce petroleum. The amount of organic matter to the southeast is expected to decrease. Gypsiferous units on the Kizıldere formation are covered rock in petroleum, therefore oil and gas exploration have reached positive results.

\section{REFERANCES}

[1]. Durand B., Espitalie, J., Et Nicaise, G., Etude De La Matiere Organique İnsoluble Des Argiles Du Toarcien De Bassin De Paris. Etude par les procedes optiques analyse elemantaire, etude microscopie et diffraction electronniques: Rev. Ist. Fr. Petr., 27 (1972) 865-884.

[2]. Dessort, D., Gelin, F., Duclerc, D., LeVan-Loi, R., Enhanced assessment of the distribution of organic matter in unconventional plays and tarmat in reservoirs using a new laser pyrolysis method on core. In: SPE 161626, presented at the Abue Dhabi International Petroleum Exhibition and Conference in Abu Dhabi, UAE, 211-14 November 2012.

[3]. Washburn, K.E., Rapid geochemical and mineralogical characterization of shale by laser-induced breakdown spectroscopy. Org. Geochem., 83-84 (2015) 114 - 117.

[4]. Charsky, A., Herron, S., Accurate, direct total organic carbon (TOC) log from a new advanced geochemical spectroscopy tool: comparisons with conventional approaches for TOC estimation. In: AAPG Paper 1547013, presented at the AAPG Annual Conference and Exhibition, Pittsburgh, Pennsylvania, 2022 May 2013.

[5]. Baumgardner, R.W., and H.S., Hamlin, Core-based Geochemical study of Mudrocks in Basinal Lithofacies in the Wolfberry Play, Midland Basin, Texas, Part II: Search and Discovery Article no. 10572, 2014.

[6]. Hunt J. M., Petroleum Geochemistry and Geology, W.H. Freeman and Company, New York, 743, 1995.

[7]. Loverson A. İ., 1967. Geologie of Petroleum: W. H. Free, Comp, SanFransisco.

[8]. Ronov, AJB., Organic carbon in sedimentary rocks: Geochemistry, 5 (1958) 496-509.

[9]. Aksu, R., Demirkol, C., Quantitative basin modeling and hydrocarbon potential of İskenderun Basin. TAPG Bulletin, 13-1 (2001) 65-117.

[10]. Kozlu, H., İskenderun Baseni jeolojisi ve petrol olanakları :TPAO Rapor no.1921, 1982.

[11]. Kozlu, H., Doğu Akdeniz Bölgesinde yer alan Neojen basenlerinin (İskenderun Misis-Andırın) tektono-stratigrafi birimleri ve bunların tektonik gelişimi. Ç.Ü. Fen Bilimleri Enstitüsü Jeoloji Mühendisligi Anabilim Dalı, Doktora Tezi, 1997; 188s.

[12]. Schmidt, G., Stratigrafic nomenclature for the Adana region petroleum distirict VII.Petroleum Administration Pub. Bull., 1961.

[13]. Kozlu, H., Stratigraphy and structural evolution around Misis-Andırın (SE 
Turkey). 7th Turkish Petroleum Congress, Ankara, Geology Announcements, pp (1987) 104-116.

[14]. Donat, D., Sinanl1-Samandağ ve Arsuzİskenderun (Hatay) Yöresi MiyoPliyosen Geçişinde Yer Alan Çökellerin Mikropaleontolojik İncelemesi ve Ortamsal Yorumu, Ç.Ü. Fen Bilimleri Enstitüsü Jeoloji Mühendisligi Anabilim Dalı, Yüksek Lisans Tezi, 2009; 133s.

[15]. Kozlu, H., Tectono-stratigraphic units of the Neogene basins (İskenderun, MisisAndırın) and their tectonic evolution in the eastern Mediterranean region.
Çukurova Univ. Natural Science Institute, Adana-Turkey, unpublished Ph.D. Thesis, 1997; 189 p.

[16]. Tekin, E., Varol, B., \& Ayyıldı, T. Sedimentology and paleoenvironmental evolution of Messinian evaporites in the Iskenderun-Hatay basin complex, Southern Turkey. Sedimentary Geology, 229-4 (2010) 282-298.

[17]. Ruble et al., Tim Ruble, Richard J. Heck, A. Drozd William Practical Geochemical Methods to Assess Unconventional Reservoirs Weatherford International Ltd., 2015. 